\title{
THE EFFECT OF USSD POP-UP NOTIFICATION ADVERTISING ON INTERESTS IN BUYING SME's PRODUCTS
}

\author{
By: \\ Erina Sovania ${ }^{1}$ \\ Annathasia Puji Erasashanti² \\ 1 \& 2) Marketing Management Study Program \\ IKPIA Perbanas \\ Email: \\ erinasovania9@gmail.com
}

\begin{abstract}
Hard to imagine if now living without a cellphone. All information can be provided quickly and instantly via mobile. Advertisements on mobile phones are becoming the current trend and target by advertisers despite the high possibility of recipients seeing and responding to the ads that appear. This study intends to measure whether the mobile USSD Pop-up Notification advertisement has an influence and relationship on consumer buying interest. The research method used is a descriptive quantitative method by collecting data through questionnaires to 385 respondents. The data analysis technique used is correlation analysis and simple linear regression. The results of the correlation coefficient test obtained the number 0.63 where the interpretation produced shows the existence of a Strong Relationship, and coefficient determination of $40 \%$, means a contribution of the variable USSD Pop-up Notification advertising can provide buying interest of $40 \%$, while the remaining $60 \%$ is influenced by other variables not examined in this study. For hypothesis testing, it can be seen that the $t$ value is 15.951 with a significance value of $0.000<0.05$ which means there is a Significant Effect between variable $\mathrm{X}$ on variable $\mathrm{Y}$. Finally, the study found that USSD Pop-up Notification advertising has a significant positive impact on consumer buying interest.
\end{abstract}

Keywords: Advertisement Notification, Notification Advertisement, Pop-up USSD, Pop-up Advertisement

\section{A. INTRODUCTION}

Much promotional media can be used to introduce products to the market, ranging from electronic media, print media, and digital media. Of course, each of these promotional media has advantages and disadvantages from various sides, if in terms of costs there are certainly expensive and some are cheap, in terms of 
exposure there are advertisements that can be displayed or seen in a mass or seen personally by the character of prospective customers/buyer/user specifically.

These days, mobile phones have a really big role in our life. No one can imagine living without mobile. Mobile messaging and marketing is starting to shake the marketing world's tree. It's direct, it's instant and there's a high probability that the recipient will respond to message not only read it (Eshra \& Bashir, 2019).

Watching advertisements is usually accompanied by a specific activity, such as watching advertisements on television will only be found if we are watching TV, or watching advertisements on YouTube if indeed we are viewing content on YouTube, or seeing billboard ads on the highway will only be done if on the street or in a vehicle. All activities of watching these ads are initiated by an activity first. What about getting advertisements that suddenly appear when we are not doing any activity, and these ads appear directly on the cellphone even though it is idle. This is an innovation because those advertisements can appear when the cellphone is not in use or an idle state. This advertisement media is called USSD Pop-up Notification.

USSD Pop-up Notification is expected to be able to provide alternative media for advertising promotions that are different from others, in terms of technology USSD Pop-up Notification is an advertising platform that automatically generates advertisements in the form of text on the cell phone layer specifically according to the filtering of users with age, gender, location, hobbies, and so on, and in terms of costs are relatively cheaper, because the payment mechanism is to use CPA (cost per acquisition) or per purchase transaction, where customers only need to respond to each time interested in buying a product simply by replying or typing number 1 which means agreeing to confirm buying a product.

In this study, the author wants to examine the USSD Pop-up Notification, whether it can contribute to the consumer's buying interest because the advertisement that appears on the cellphone screen is only in the form of writing or narrative offering a Lebaran cake product without showing the image or the image of the cake product.

\section{B. LITERATURE REVIEW}

\section{Advertisement}

Advertising is an activity of informing, informing, and delivering goods and services to the general public both through printed electronic media, online, and so on. Media used include television, radio, newspapers, magazines, the internet, social media, mobile phones, and so on.

Advertising activities have activities related to two fields namely economics and communication. In the field of advertising, the economy can act as a strategic effort marketing, while in the fields advertising communication plays an important role to involve parties sponsors (advertisers), electronic media, and advertising agencies (Wirapraja, 2018). According to (Kotler \& Armstrong, 2012) advertising is all forms of non-personal presentation and promotion of ideas, goods, or services by certain sponsors who need a payment. 
Indeed advertising is a way of communicating to the masses through electronic media, print, internet, even social media, and so on. So advertising has a non-personal nature and is a tool to promote a product and service for a certain fee.

Mobile advertising is the sending and receiving of advertisements by mobile devices (Hashim \& Normalini, 2018). Mobile advertising makes consumers to be involved with organization products information and transactional with the brand being promoted to them (Usman \& Mohammed, 2012).

The basic features of mobile marketing are the mobile advertisements and they can be applied to send personalized, informative, remindful, or convincing advertisement messages, depending on the place, date, and benefits of the consumers via mobile policies (Ene \& Özkaya, 2015).

Advertisement with mobile can greatly target customers who find advertisements through mobile appropriate and valuable, and therefore are to be expected a response from them by purchasing or connecting (Usman \& Mohammed, 2012).

\section{Notification Pop-up USSD Advertisement}

A pop-up advertisement is an advertisement that seems suddenly on the monitor screen in front of the page when opening a website (Moriarty, 2011). Push Notification is a service that is widely used for notification purposes via short messages on smartphones. With the Push Notification service, users can be helped in terms of short notice (Siddik, 2018).

A pop-up advertisement is more advantageous to large multinational, small, and medium-sized companies as well as all non-profit and government agencies. With the help of a pop-up advertisement company and consumers can actively interact with each other. It allows consumers to like certain advertisements and react to it (Longani \& Kirti, 2018).

A Pop-up notification platform that is used to display an event or advertisement with a block notification display on the mobile screen display, the Pop-up is used so that notifications that enter the cellphone can be seen easily because the appearance can be seen directly when the cellphone receives a notification Pop-up. Pop-up notifications have sophisticated features such as database profiling, where advertisements that appear on the mobile screen are following the characteristics of the mobile user.

Notification Pop-ups that appear there are only or limited to provide advertising information about offers or promos, or there is also a Notification Popup in the form of UMB is an offer menu that appears on the cellphone screen that can be directly responded to by cellphone users by typing numbers according to choices, for example, type or reply with number 1 to agree to buy.

UMB stands for USSD Menu Browser, where USSD is a protocol used to communicate from a user's mobile phone or handset to a telecommunications service provider (and vice versa). Standing for USSD is Unstructured Supplementary Service Data. 
UMB generally uses the HTTP protocol format as its access interface both from the UMB to the Content Provider (CP) and the response messages from the Content Provider to the UMB. UMB Developer itself is part of the USSD Application. The message format used is generally the HTTP protocol with the GET command or commonly called the HTTP Get method only when requesting the CP side and as a response from the CP, the side is XML. HTTP Get is carried out meaning that the Operator side will trigger or direct the service towards Content Application.

Access to USSD can be called SMS marketing software and USSD itself is a GSM technology that is often used as an additional service access to the SMS center application.

How to access USSD must be preceded by an asterisk (*) then followed by a series of numbers and then ended with a hash mark (\#). The number that exists between the two marks is a certain code number, but because it uses the sign the call to that number will be marked as a call to USSD. In contrast to SMS, with USSD we access it in real-time just as we are talking to someone over the telephone. The USSD Menu Browser (UMB) is an application from USSD that provides interactive menu management with customers in providing information or offers or promos of products and services.

The use of UMB is easily accessible, just need to press the number (access code) you want.

In https://myadvertisement.telkomsel.com/ states that UMB has 2 transaction modes, namely:

1. Pull mode or mobile-initiated, ie interaction initiated (initialization) from the user's mobile phone, or service that requires get the message/customer who receives an advertisement message to call the message via a special number or code (shortcode)

2. Push mode or network-initiated, the interaction that starts (initialization) of an application that is on the operator's network, or a service that allows recipients of messages/customers to receive messages to directly be able to receive advertising messages in the form of pop-up messages without having to call numbers or special code.

UMB mode which will be examined in this study is for point 2, namely Push Mode.

The challenge of the USSD Pop-up notification ad is the limited number of letter characters that can be displayed on a mobile screen, only 160 characters. So the narrative of the advertisements delivered must be really interesting, creative, provoking consumers' curiosity about the products offered in full containing information such as type/product name, price, contact number that can be contacted, etc. So that the message delivered can be understood and accepted by readers or recipients of Pop-up notification advertisements so that after reading the USSD Pop-up notification ad, it will raise consumer interest in buying the product.

\section{Buying Interest}

Is the process that exists between alternative evaluations and purchasing decisions. After consumers evaluating existing alternatives, consumers have an interest in buying a product or services offered (Putri, 2016). 
Buying interest is related to the consumer's plan to buy a particular product and how much to buy, it can be stated that buying interest is a mental statement from consumers that reflects the plan to buy several products with a certain brand (Firdaus, 2017).

Buying interest is also defined as consumer interest in a product by seeking more information (Shahnaz, 2016). Interests arising in buyers are often in conflict with their financial condition. Consumer buying interest is a hidden want in the minds of consumers, consumer buying interest is something that is always shrouded in consumers where no one can know what the consumer desires, all that producers do is only predict about things that might be cooled by consumers, but the truth is that it will only be known by the consumer himself.

The main fundamental aspect of consumer behavior is buying intention which is defined as a situation where the customer is agreeable to conduct transactions with the (Burhanudin, 2017).

There are stages of the producer in determining buying interest in making purchases of products or services offered, it can be seen in the AIDA concept or model developed by (Kotler \& Keller, 2012), namely: Attention, Interest, Desire, Action. The definition of AIDA is as follows:

1. Attention This stage is the first stage in assessing a product or service following the needs of prospective customers, in addition to prospective customers also learn the products or services offered.

2. Interest In this stage prospective customers begin to be interested in buying the product or service offered, after getting more detailed information about the product or service offered.

3. Desire Prospective customers begin to think about and discuss the products or services offered because they want and want to buy began to arise. In this stage, prospective customers have started to be interested in the products or services offered. This stage is marked by the emergence of strong interest from potential customers to buy and try the products or services offered.

4. Action At this stage prospective customers already has high stability to buy or use the products or services offered.

\section{Small and Medium Enterprises}

Small and Medium Enterprises (SMEs) in its development has increased very rapidly in number. SME is now one of the important components in the national industry because it has a very important role in the national economy that can help to absorb labor, fair distribution of development results, and poverty reduction (Dwi, 2014). Small enterprises are generally considered to be more operative, can respond quickly, and are more flexible than big companies, which form their strategies for years ahead (Behara, 2017).

In general, SME (Small and Medium Enterprise) is a business that has a productive business entity or person and meets the terms and conditions as a micro class business. Usually the category a business is micro or macro seen from the large turnover and the net worth of the entrepreneur himself. For types of small businesses or SME having a net worth of at most Rp. 200,000,000 excluding land and buildings where the business is located. 
According to Keputusan Presiden RI no. 99 years 1998 the definition of Small Business is a small-scale people's economic activity with a business sector that is predominantly a small business activity and needs to be protected to prevent unfair business competition. Small and Medium Enterprise (SME) according to Law No. 20 of 2008 is divided into two terms, namely: small businesses are entities that have a net worth of more than Rp 50,000,000.00 (fifty million rupiahs) up to a maximum of Rp 500,000,000.00 (five hundred million rupiahs) not included land and building of business premises, as well as having annual sales results of more than Rp $300,000,000.00$ (three hundred million rupiahs) up to a maximum of $\mathrm{Rp}$ 2,500,000,000.00 (two billion five hundred million rupiahs).

Then a medium business is a business entity that has a net worth of more than $\mathrm{Rp} 500,000,000.00$ (five hundred million rupiahs) up to a maximum of $\mathrm{Rp}$ $10,000,000,000.00$ (ten billion rupiahs) excluding land and buildings where it operates and has a yield annual sales of more than $\mathrm{Rp} 2,500,000,000.00$ (two billion five hundred million rupiahs) up to a maximum of $\mathrm{Rp} 50,000,000,000.00$ (fifty billion rupiahs). According to (Tohar M. , 2010) the definition of small business is divided in several aspects as follows:

a) Based on total assets. Small entrepreneurs are entrepreneurs who have a net worth of at most Rp. 200,000,000 excluding land and buildings where businesses are opened.

b) Based on total sales. Small entrepreneurs are entrepreneurs who have a total net sales/year of at most Rp 1,000,000,000.

c) Based on the ownership status. Small entrepreneurs are businesses in the form of individuals that can be incorporated or not incorporated, including cooperatives.

\section{Framework}

Pop-up notification advertising is a form of communication delivery in the form of product offerings that appear on the user's mobile screen in the form of text, no visuals such as pictures and sounds. The purpose of Pop-up notification advertisements is to influence people's attitudes, in this case, of course, to create buying interest in Lebaran cake and cookies products offered, therefore Pop-up notification advertisement is designed appropriately so that the products offered are correct well received by consumers.

Because the Pop-up Notification ad is only in the form of text that is no more than 160 characters, the message or narration that is displayed must be informative and persuasive, include the price so that the user knows the price of Lebaran cakes and cookies offered is not expensive or the price is relatively acceptable, and the most important thing is that the product must be necessary or proper and fit the momentum. During the Lebaran Day event, who doesn't need a cake? who celebrate Lebaran need a cake and cookies.

An interesting message, the right product price, and the product that is needed, then in the end there will be a buying interest in the consumer. As stated by (Wijaya, 2015) effective advertising will attract attention, and then consumers process information, and then a positive or negative attitude towards the advertisement appears, eventually leading to buying interest. 
(Longani \& Kirti, 2018) stated that there was a positive relationship between consumer awareness and consumer perceptions in motivating the consumer to buy a certain product through Pop-up Ads on the internet. And (Wang \& Ampiah, 2014) stated that the study of pop-up ads is not effective in influencing the purchase behavior of social media users.

Both of their research is on an internet basis/ channel. In this study, what will be tested are pop-up ads that do not use the internet channel, but through the USSD platform, after that determine the relationship between consumers' buying interest. The conceptual framework of this study is developed and shown in Table 1.1 as follows:

Tabel 1.1

Frameworks

\begin{tabular}{|l|l|}
\hline \multicolumn{1}{|c|}{ Pop-Up ads (X) } & \multicolumn{1}{|c|}{ Buying Interest (Y) } \\
- Message & - Consumer Attention \\
- Price of Product & - Interest \\
- Types of Product & - Desire \\
- Momentum & - Action \\
\hline
\end{tabular}

\section{Research Hypothesis}

$\mathrm{H}_{0} \quad$ : There is no significant effect between Pop-up notification advertisements on interests buy

$\mathrm{H}_{1} \quad$ : There is a significant effect between Pop-up notification advertisements on buying interest

\section{RESEARCH METHODS}

The data used in this study are primary, i.e. data obtained directly from the source. Primary data in this study are answers from consumers who are respondents. The population in this study was visitors who attended the SME product bazaar event at Menara Jamsostek Building, where the event was held for 3 days with an estimated visitor of 900 people. To meet the minimum sample size to represent the population of respondents being studied, then the researchers find the number of samples using the formula as below (Zikmund, 2010):

$$
n=\frac{\left(Z \frac{a}{2}\right)^{2} \cdot p \cdot q}{e^{2}}
$$

This study uses a precision level of $(\alpha)$ of $5 \%$ as well as a confidence level of $95 \%$ so that the $(Z)$ value obtained in the standard normal distribution table is 1.96 . The error rate $(e)$ is set at $5 \%$. Meanwhile, $(q)$ on the probability of the questionnaire is accepted at $50 \%$ and $(p)$ on the probability of the questionnaire being wrong (rejected) by $50 \%$, the calculation of the sample number is 384.16 and rounded up to 385 . 
Based on the above calculation, the number of samples to be used in this study amounted to 385 respondents. Respondents in this study are men and women aged 25 to 40 years who have seen examples of Pop-up notification advertisements appearing on mobile phones. Data collection used by the author is to use a questionnaire, each question is accompanied by five possible answers that must be chosen by respondents.

Because this research is a correlational study, to detect the extent to which variations in a factor are related to variations in one or more other factors based on the correlation coefficient, the variables used in this study are:

1. Independent Variable (X), is "Pop-up Notification Advertisement"

2. Dependent Variable (Y), is "Buying Interest"

The following is for the Pop-up Notification Advertisement Display image:
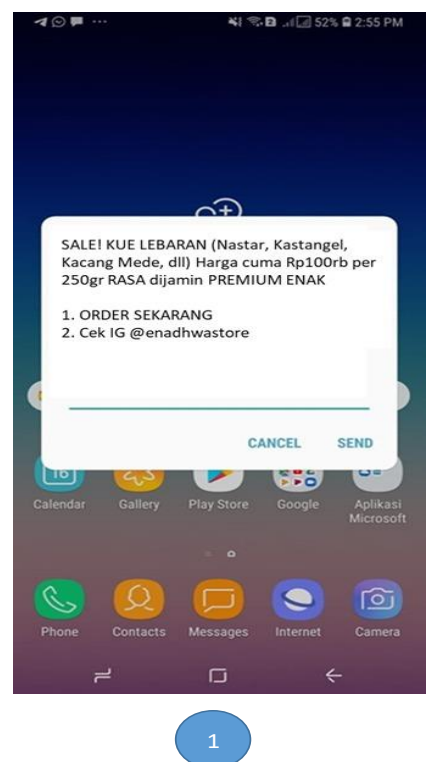

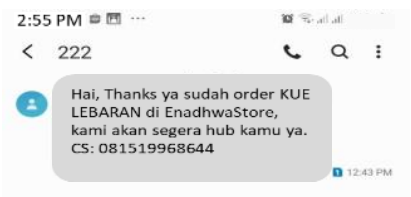

Tuesday, Mav 28,2019
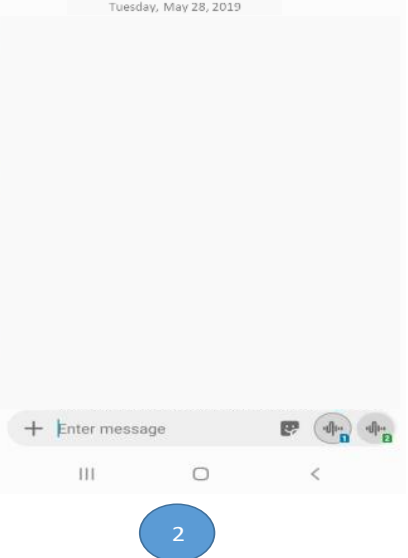

Image: 1

Pop-up Notification Advertisement Display

\section{RESULTS AND DISCUSSION}

\section{Validity Test}

Validity Test is the level of reliability and validity of the measuring instruments used. The instrument is said to be valid, meaning that the measuring instrument used to obtain the data is valid or can be used to measure what should be measured. The validity test aims to find out if there are statements on the questionnaire that must be replaced because they are considered invalid.

To test the validity of this measuring tool using the help of Microsoft Office programs, namely Excel. The following table shows the results of Validity testing, which are as follows:

Table: 2

Validity Test 


\begin{tabular}{|c|c|c|c|c|c|c|c|c|}
\cline { 2 - 9 } \multicolumn{1}{c|}{} & \multicolumn{4}{c|}{ Question } & \multicolumn{4}{c|}{ Question } \\
\cline { 2 - 9 } \multicolumn{1}{c|}{} & $\mathbf{1}$ & $\mathbf{2}$ & $\mathbf{3}$ & $\mathbf{4}$ & $\mathbf{5}$ & $\mathbf{6}$ & $\mathbf{7}$ & $\mathbf{8}$ \\
\hline $\mathbf{r}_{\mathbf{x y}}$ & 0,443 & 0,515 & 0,622 & 0,595 & 0,533 & 0,563 & 0,540 & 0,488 \\
\hline $\mathbf{t}_{\text {count }}$ & 9,670 & 11,752 & 15,540 & 14,479 & 12,324 & 13,334 & 12,542 & 10,956 \\
\hline $\mathbf{t}_{\text {tabel }}$ (alpha = $\mathbf{0 , 0 5 , n - 2 )}$ & 1,649 & & & & & & & \\
\hline Note & VALID & VALID & VALID & VALID & VALID & VALID & VALID & VALID \\
\hline Total valid & 8 & & & & & & & \\
\hline
\end{tabular}

From Table 2 above, it appears that all questionnaire questions were raised to 385 respondents. T table value is obtained through $\mathrm{df}$ (degree of freedom) $=\mathrm{n}-2$, i.e. $\mathrm{df}=385-2=383$ with $\alpha=0.05$ or $5 \%$, the $\mathrm{t}_{\text {table }}$ value $=1,649$. The results of the calculation of the validity of 8 (eight) questions appear to have a greater $t_{v a l u e}$ than $\mathrm{t}_{\text {tables }}$ so that all eight questions are declared Valid.

\section{Reliability Test}

Reliability test (reliability) is carried out to determine the extent to which an instrument can provide relatively the same results if it is measured again on the same subject (Sugiyono, 2010). The following is the calculation of the reliability test (reliability) of the instruments contained in the Pop-up notification advertising and purchase intention variables.

Table: 3

Reliability Test

\begin{tabular}{|c|c|c|c|c|c|c|c|c|}
\cline { 2 - 9 } \multicolumn{1}{c|}{} & \multicolumn{7}{c|}{ Question } \\
\cline { 2 - 9 } \multicolumn{1}{c|}{} & $\mathbf{1}$ & $\mathbf{2}$ & $\mathbf{3}$ & $\mathbf{4}$ & $\mathbf{5}$ & $\mathbf{6}$ & $\mathbf{7}$ & $\mathbf{8}$ \\
\hline Var Item & 1,462 & 1,626 & 1,693 & 1,615 & 1,532 & 1,605 & 1,531 & 1,355 \\
\hline SVar Item & 12,420 & & & & & & & \\
\hline SVar Total & 31,505 & & & & & & & \\
\hline$r_{11}$ & 0,692 & & & & & & & \\
\hline Category & High & & & & & & & \\
\hline
\end{tabular}

Values for reliability testing come from valid questionnaire item scores. The instrument has a high level of reliability if the coefficient value obtained $>0.60$.

From the results of the above output obtained an alpha value of 0.692 , so it can be concluded that these items are reliable, and belong to the category of High Reliability $\left(r_{11}>0.60\right)$.

Table: 4

\section{Linear Regression Output}

SUMMARY OUTPUT

\begin{tabular}{lr}
\hline \multicolumn{2}{c}{ Regression Statistics } \\
\hline Multiple R & 0,631801825 \\
R Square & 0,399173546 \\
Adjusted R Square & 0,397604809 \\
Standard Error & 2,364711503 \\
Observations & 385 \\
\hline &
\end{tabular}




\begin{tabular}{|c|c|c|c|c|c|c|c|c|}
\hline & $d f$ & $S S$ & $M S$ & $F$ & Significance $F$ & & & \\
\hline Regression & 1 & 1422,878 & 1422,878 & 254,4553 & $2,74307 \mathrm{E}-44$ & & & \\
\hline Residual & 383 & 2141,683 & 5,59186 & & & & & \\
\hline \multirow[t]{2}{*}{ Total } & 384 & 3564,561 & & & & & & \\
\hline & Coefficients & Standard Error & t Stat & $P$-value & Lower 95\% & Upper $95 \%$ & Lower $95.0 \%$ & Upper $95.0 \%$ \\
\hline Intercept & 4,877228774 & 0,464544 & 10,49895 & $7,86 \mathrm{E}-23$ & 3,963852304 & 5,790605244 & 3,963852304 & 5,790605244 \\
\hline $\mathrm{X}$ Variable 1 & 0,607824161 & 0,038104 & 15,95165 & $2,74 \mathrm{E}-44$ & 0,532904661 & 0,682743662 & 0,532904661 & 0,682743662 \\
\hline
\end{tabular}

Based on the results of data processing using Microsoft Excel, the results obtained that the regression equation is:

$$
Y=4,8772+0,6078 X
$$

From the above equation, it is known that the constant value (fixed) consumer buying interest is 4,8772, and the coefficient value of Pop-up notification advertisement is 0.6078 which means that each Pop-up notification ad (X) increases by $(1 \%)$ then consumer buying interest $(\mathrm{Y})$ will increase by 0.6078 or $60 \%$.

\section{Correlation Coefficient Results}

According (Ghozali, 2012) guidelines for providing an interpretation of correlation coefficients are as follows:

- 0.00 - 0.199: very low

- 0,20 - 0,399: low

- 0.40 - 0.599: moderate

• $0.60-0.799$ : strong

- 0.80 - 1,000: very strong

Based on the results of the calculation output in table 4 for the correlation coefficient (multiple R), the number 0.63 is obtained where the interpretation produced in this study shows a strong relationship between Pop-up notification advertisements with consumer buying interest.

\section{The Coefficient Of Determination Results}

The coefficient of determination $r^{2}$ is used to see how much the independent variable (advertising notification Pop-up) is influenced by the dependent variable (buying interest), or in other words how much the independent variable influences the dependent variable, and based on the results of the calculation output in Table $4 \mathrm{R}_{\text {Square }}$ value of $40 \%$ means the role or contribution of Pop-up notification advertising variables can explain the purchase interest variable by $40 \%$, while the remaining $60 \%$ is influenced by other variables not examined in this study.

\section{Hypothesis Test Results}

Hypothesis test results are conducted to determine whether there is a relationship between variables (X) and variables (Y) by calculating the correlation. If the acceptance of $\mathrm{H}_{0}$ occurs, it can be concluded that influence is not significant, whereas if $\mathrm{H}_{0}$ is rejected, it means that influence is significant. Based on the results of the output in Table 4 can be known the value of t-arithmetic is 15,951 with a significance value of $0,000<0,05$ then $\mathrm{H}_{0}$ is rejected and $\mathrm{H}_{1}$ can be accepted, 
which means there is a significant influence between the Pop-up notification advertising variable $(\mathrm{X})$ on the purchase interest variable $(\mathrm{Y})$.

\section{E. CONCLUSIONS}

Based on the results of the study related to the influence of the USSD Pop-up notification advertisement on consumer buying interest, the conclusions obtained are as follows: The USSD Pop-up notification advertisement for Lebaran cake products shows a strong relationship between advertising with consumer buying interest, where the value obtained is 0.63 or $63 \%$ with the interpretation of a category that is having a strong relationship. This means that the promotion of Lebaran cakes advertised through the USSD Pop-up notification that appears on the consumer's cell phone screen directly is appropriate and can be tried because the delivery of information displayed is quite effective, simple but interesting because the ad provides detailed information on what products are offered, how much they are, and the momentum element also plays a role because before Lebaran. Based on the coefficient of determination, the USSD Pop-up notification ad has an effect of $40 \%$ meaning the role or contribution of the USSD Pop-up notification advertising variable can explain the purchase interest variable by $40 \%$, while the remaining $60 \%$ is influenced by other variables not examined in this study.

Previous research (Longani \& Kirti, 2018) stated that there was a positive relationship between consumer awareness and consumer perceptions in motivating the consumer to buy a certain product through Pop-up Ads on the internet. And (Wang \& Ampiah, 2014) stated that the study of pop-up ads is not effective in influencing the purchase behavior of social media users, it reveals that users of social media have a negative attitude towards pop-up ads mainly because of its intrusive/obstructive nature. As a result, these ads are not positively influencing their purchase behavior. In other words, the products/services advertised through pop-up ads do not appeal to the users.

In the two previous studies, all of them used internet channels, and the results of these two studies were positive and negative. Whereas in this study not using internet channels at all, but through the USSD platform. As stated in literature Access to USSD can be called SMS marketing software and USSD itself is a GSM technology that is often used as an additional service access to the SMS center application. To reach USSD must be preceded by an asterisk (*) then followed by a series of numbers and then ended with a hash mark (\#). To respond to the ads, the recipient just needs to answer and give a feedback with reply number for example with press 1.

Pop-up ads via the internet have disturbing implications for users who are watching content, because the presence of advertisements is not expected, only distracting them. While pop-up ads via USSD easily appear when the user is not active on their cellphone, so the ads are like delivering information in the form of offers.

The USSD Pop-up notification ads can be an alternative promo channel for all products, included SME products. In terms of features, these USSD Pop-up notification ads are technologically capable of filtering or sorting to whom or what 
market segments are expected to receive this ad so that the target is more optimal and focused.

\section{REFERENCES}

Behara, S. R. (2017, August). Importance Of Managerial Skills And Knowledge In Management For Small Entrepreneurs. International Journal of Management Marketing, 3(2), 21-30.

Burhanudin, R. (2017). Pengaruh Iklan Traveloka di Televisi terhadap Minat Beli Konsumen. e-Proceeding of Management, 4 No.2, pp. 1453-1459.

Dwi, W. (2014, Oktober). Pengaruh Harga, Desain Produk, Kualitas Produk dan Citra Merek Terhadap Keputusan Pembelian. Jurnal Bisnis Teori dan Implementasi, 5 No. 2, 206-218.

Ene, S., \& Özkaya, B. (2015). The Role of Mobile Advertising on Consumers' Purchase Decisions: A Research on Consumer Attitudes towards Mobile Advertising. International Journal of Humanities and Social Science, 5 No. $1,235-248$.

Eshra, D., \& Bashir, D. N. (2019). Effect of Consumer Attitude towards SMS Advertising and Demographic Features on Egyptian Consumers Buying Decision. Journal of Marketing Management, Vol. 7, No. 2, 70-76. Retrieved December 2019

Firdaus, A. d. (2017). Pengaruh Strategi Pemsaran Terhadap Minat Konsumen Membeli Produk Perumahan Surya Mandiri Teropong PT Efa Artha Utama. Jurnal Ilmu Administrasi Fakultas Ilmu Social dan Pilitik Universitas Riau, 4 No.1, 1-12.

Ghozali, I. (2012). Aplikasi Analisis Multivariate dengan Program IBM SPSS. Yogyakarta: Universitas Diponegoro.

Hashim, N. H., \& Normalini, N. a. (2018). The Influence Factors towards Mobile Advertising Message Content on Consumer Purchase Intention. Global Business Review, Vol.19, No.5, pp. 1187-1206.

Kotler, P., \& Armstrong, G. (2012). Prinsip-prinsip Pemasaran (13 ed., Vol. 1). Jakarta, DKI Jakarta, Indonesia: Erlangga.

Kotler, P., \& Keller, a. K. (2012). Marketing Management (14 ed.). United States of America: Pearson Education.

Longani, D., \& Kirti. (2018, December). Impact And Effectiveness Of Advertising Through Pop Ups On Internet On Young Working Women's Buying Behaviour - A Scale Validation Study In Pune City. International Journal of Modern Trends in Business Research, 1(5), 53-69. 
Moriarty. (2011). Advertising Edisi Kedelapan. Jakarta. Jakarta: Kencana Prenada Media Group.

Putri, C. S. (2016). Performa: Jurnal Manajemen dan Start-Up Bisnis. 1, $594-603$. Retrieved December 2016

Shahnaz, F. B. (2016). Faktor yang Mempengaruhi Minat Konsumen di Toko Online. Managemen Analysis Journal, 1-11.

Siddik, M. (2018). Perancangan Aplikasi Push Notification Berbasis Android. JURTEKSI (Jurnal Teknologi dan Sistem Informasi), 4 No. 2, 149-154. Retrieved June 2018

Sugiyono. (2010). Metode Penelitian Pendidikan Pendekatan Kuantitatif, kualitatif, dan $R \& D$. Bandung, East Java, Indonesia: Alfabeta.

Tohar, M. (2010). Membuka Usaha Kecil. Jakarata, DKI Jakarta, Indonesia: Kanisius.

Usman, U. M., \& Mohammed, Z. B. (2012). The Impact of Mobile Advertisement and Communication on Customer Relationship Management. International Conference on Economics, Business and Marketing Management, 29, pp. 118-121.

Wang, L., \& Ampiah, F. (2014). The Influence of Pop-up Advertising on Consumer Purchasing Behavior A case study of social media users in Ghana. Atlantis Press International Conference on Mechatronics, Electronic, Industrial, and Control Engineering (MEIC 2014).

Wijaya, P. (2015, Oktober). Pengaruh Pesan Iklan, Keterlibatan Iklan, Kredibilitas, dan Kecocokan Endorser Pada Minat Beli Melalui Sikap Konsumen. Jurnal Siasat Bisnis, 19 No. 1, 36-55. Retrieved January 2015

Wirapraja, A. (2018). Pengaruh Efektivitas Iklan Terhadap Tingkat Minat Beli Mie Instant (Studi Kasus Mie Sedaap White Curry). Jurnal EKSEKUTIF, Volume 1 No. 1, 98-113. Retrieved June 2018

Zikmund, W. G. (2010). Business Research Methods (8 ed.). South-Western, USA:: Cengage Learning.

Web Page:

https://myadvertisement.telkomsel.com/ 